\title{
Reference, reading, and nonreading \\ Learning from Bayard (with a grain of salt)
}

$\mathbf{T}$

his spring I had the opportunity to teach an undergraduate course on the history of philosophy from René Descartes to William James. On most of our twice-weekly class sessions, I would bring a half-dozen or so books with me beyond the anthology we were working from. My duty as a librarian impelled me-there are riches untold (to freshman, at least) in our stacks, waiting to be unveiled. Usually these books were pulled haphazardly from my office shelves just before class. Sometimes they were checked out from our library, less often requested from elsewhere a week or two ahead of time because I actually knew what I wanted to talk about that far in advance. I would bring secondary literature to recommend for further research, other unassigned works by authors we were reading in the event that a first exposure might have sparked philosophical discipleship, along with living thinkers like Seyla Benhabib or Giorgio Agamben who have fruitfully picked up the threads of the Enlightenment problems we were considering.

For the first lecture of the semester, on the rise of early modern natural philosophy, I brought Wilhelm Schickard's 1632 De Mercurio Sub Sole Viso. It was probably the oldest book any of them had actually held in their hands, and I was hoping to wow them, perhaps drawing a few of them wide-eyed into a newfound love of very old books.

Toward the end of the semester, in the midst of talking through another pile of books, one of my students raised his hand and asked, "Have you actually read all the books that you show us?" It was a wonderful question.

"No!" was the short answer, which I volunteered immediately. I then thumbed through that day's stack of books and identified which ones I had read in full, partially, or not at all. I had just read Martin Mulsow's Enlightenment Underground for a review, but only knew the sections on Germany from Jonathan Israel's door-stopping Radical Enlightenment.

Then I explained to them a way of relating to texts that is familiar to librarians-how one must constantly jockey between the individual and the whole, seek to understand the context of a text's contribution to the world in order to better understand that text, and subsequently integrate this understood text into its wider context before moving forward to as-yet unencountered ones.

I went on to recommend Pierre Bayard's How To Talk About Books You Haven't Read, ${ }^{1}$ and I'm only somewhat sorry to say that I relished adding the now-passé qualification offered by many a critic on Bayard: "I haven't actually read the book, but. ..."

Evan F. Kuehn is theology librarian at Trinity International University's Rolfing Library, email: efkuehn@tiu.edu

(c) 2017 Evan F. Kuehn 
I received the intended laugh for the canned performative reinscription, but was also able to make the important point that (I assumed) Bayard also wanted to make: there will always be relevant books left unread, and we need to be comfortable with bibliographic synthesis and measured opinion in the absence of comprehensive reading.

I have since gotten around to actually reading Bayard, and my attempted version of his thesis holds up relatively well. Nonreading is the key for Bayard. While we may not like to admit it, this is the default relationship that we have with books, even those that we know well, recommend to our patrons, or catalog. The fact that we will not read the vast majority of books does not mean that we cannot understand them in a meaningful way.

How to Talk About Books You Haven't Read is a therapeutic jaunt toward confidence in the face of a veritable flood of literature. This is what Bayard argues in the first half of the book, at least, which I would recommend to any librarian (the second half moves into territory with which I am not sympathetic-the idea of literary criticism as autobiography. Here the wit that served as a vehicle for decent advice ends up recommending anti-social literary tendencies).

Bayard's account is not entirely innocent, however. In his $M L N$ essay "Pierre Bayard and the Death of the Reader," Jack Abecassis identifies the important point that Bayard fails to make: "truly productive non-reading is parasitical on the right kind of prior reading." ${ }^{2}$

At his best, Bayard only reassures us in the face of anxiety about the daunting totality of published literature. We can and do incorporate books we have not experienced into our literary horizon, and further, there is nothing shameful about this in itself. But Bayard's criticisms of reading are as onesided as Nietzsche's criticisms of the philologists. They are playful and even worth taking to heart, but disastrous if taken as the whole story. Bayard and Nietzsche both are only in a position to offer the sort of
Then I explained to them a way of relating to texts that is familiar to librarians-how one must constantly jockey between the individual and the whole, seek to understand the context of a text's contribution to the world in order to better understand that text, and subsequently integrate this understood text into its wider context before moving forward to as-yet unencountered ones.

critique that they do because of their debts to normally functioning academic reading (or philologizing). Again, their contribution is ultimately parasitic on doing some things the old-fashioned way.

For the librarian whose job it is to cultivate unread books and get them into the hands of the research community, "the old-fashioned way" means a good deal of actual reading, even if it will only ever make a slight dent in the massive superstructure of the whole.

As a theological librarian this means that I need to know linguistic reference works and canons both of scriptures and interpretative literature, a broad arc of ecclesiastical histories, and the important turf wars of living theorists of religion, and especially of religious theorists of religion. For liaisons to other disciplines, or even for religion liaisons at different sorts of institutions than my own, the territory will be different, and so also will the map. But the fundamental duty of meticulous reading will always accompany the call to confident nonreading. It is not a task that will become outdated as the vocation of the library changes.

\section{Notes}

1. Pierre Bayard, How to Talk About Books You Haven't Read. trans. J. Mehlman (New York: Bloomsbury, 2007).

2. Jack Abacassis "Pierre Bayard and the Death of the Reader," MLN 125.4 (2010): 961-979. $\neq 2$ 